\title{
Relationship of thyroid peroxidase antibody test with abnormal thyroid function tests
}

\author{
Khadka Shrestha Srijana ${ }^{1}$, Karmacharya Kavita², Giri Mimi ${ }^{3}$, Bajracharya Manil \\ $\mathrm{Raj}^{3}$, Jha Sandeep ${ }^{4}$

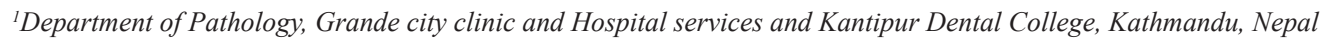 \\ ${ }^{2}$ Department of Pathology, Grande city clinic and Hospital services, Kathmandu, Nepal \\ ${ }^{3}$ Department of Endocrinology, Grande city clinic and Hospital services, Kathmandu, Nepal \\ ${ }^{4}$ Grande city clinic and Hospital services, Kathmandu, Nepal
}

\section{Keywords: \\ Autoimmune; \\ Thyroid; \\ Thyroid function test; \\ Thyroid peroxidase autoantibody}

\begin{abstract}
Background: Autoimmune thyroid disease results from a complex interaction between genetic and enviromental factors. The aim of this study was to find association of anti-thyroid peroxidase antibody with abnormal thyroid function tests.
\end{abstract}

Materials and Methods: This is a retrospective study, conducted in 160 patients who showed abnormal thyroid function tests in grande city clinic and hospital services and Kantipur dental college for duration of 18 months since Baisakh 2072.

Results: Among 160 individuals , 126(78.8\%) were female and 34(21.2\%) were male. Subclinical hypothyroidism (56.3\%) were most common than overthyperthyroidism (18.0\%), overthypothyroidism (16.9\%) and subclinical hyperthyroidism (8.8\%). Anti thyroid peroxidase antibodies test was shown positive in 102/160 (63.8\%) cases.

Conclusion: According to the present study, anti- thyroid peroxidase antibody has been significantly associated with thyroid dysfunction, it can be used as diagnostic marker for thyroid autoimmune diathesis.

\section{Correspondence:}

Dr. Srijana Shrestha Khadka, MBBS, MD

Assistant Professor, Department of Pathology

Grande city clinic and Hospital services and

Kantipur Dental College, Kathmandu, Nepal

ORCID ID: 0000-0003-0148-7394

Email: srijanak82@gmail.com

Received : June 23rd, 2017 ; Accepted : August 1st, 2017; Published : September 1, 2017

Citation: Khadka Shrestha S, Karmacharya K, Giri M, Bajracharya MR, Jha S. Relationship of thyroid peroxidase antibody test with abnormal thyroid function tests. J Pathol Nep. 2017;7: 1172-5 doi: 10.3126/jpn.v7i2.18001doi: 10.3126/jpn.v7i2.17996

Copyright: This is an open-access article distributed under the terms of the Creative Commons Attribution 4.0 International License, which permits unrestricted use, distribution, and reproduction in any medium, provided the original author and source are credited.

\section{INTRODUCTION}

Among the autoimmune diseases of thyroid gland, three cases of Grave disease with hyperthyroidism were first described by Robert Graves in 1835.Then,in 1912, Hakaru Hashimoto reported four cases of goiter with lymphocytic infiltration, which he called "struma Lypomatosa". Belyavin and Trotter, in 1959, described about the autoantibodies reactive to thyroid gland-specific antigen called "microsomal antigen" in the sera of a patient with Hashimoto thyroiditis. Many years later microsomal antigen was identified as thyroid peroxidase (TPO), the key enzyme in the biosynthesis of thyroxine (T4) and tri-iodothyronine (T3). Thyroid Perioxidase catalyzes the iodination of tyrosine residues to form monoiodotyrosine and diiodotyrosine. 
Thyroid Perioxidase further enhance the coupling of hormonogenic monoiodotyrosine and diiodotyrosine with thyroglobulin to form T3 and T4. ${ }^{1,2}$

Anti-Thyroidperoxidase(anti-TPOAbs), anti-thyroglobulin (anti-TgAbs) and antibodies to the thyroid stimulating hormone receptor (anti-TSHRAbs) are three major autoantibodies of autoimmune thyroiditis. They can be measured in patient sera using complement fixation or immunofluorescence on thyroid tissue sections,most commonly by enzyme-linked immunoassay. ${ }^{2,3}$

Anti-TPOAb is more likely to be pathogenically important than other autoantibodies as it fixes complement and directly causes damage to thyroid cells. Anti-TPOAb reflects lymphocytic infiltration even in subclinical state of thyroid dysfuction. ${ }^{2,4,5}$ The present study has evaluated anti-TPOAb level in patients with abnormal thyroid function test.

\section{MATERIALS AND METHODS}

The present study was conducted in grande city clinic and hospital services and Kantipur Dental college for duration of 18 months since Baisakh 2072. Permission was obtained from institutional review committee.

Free T3, Free T4 and TSH were measured using the VITROS reagent pack and VITROS calibrators on the VITROS ECI/ECIQ immunodiagnostic systems, the VITROS 3600 Immunodiagnostic system and VITROS 5600 Integrated system, a direct labelled antibody, competitive immunoasssay technique .

Test for Anti TPO antibodies was performed using enzyme -linked immunosorbent assay (ELISA- EuroDiagnostica). The ELISA is intended for the qualitative determination of IgG antibodies in human serum directed against TPO.

Measuring range of Free T4 in the system is $0.07-6.99 \mathrm{ng} /$ $\mathrm{dl}$ with euthyroid reference interval of $0.78-2.19 \mathrm{ng} / \mathrm{dl}$. Measuring range of Free T3 in the system is $0.50-22.8 \mathrm{ng} /$ dl with euthyroid reference interval of $2.77-5.27 \mathrm{ng} / \mathrm{dl}$. Measuring range of TSH in the system is $0.015-100 \mathrm{uIU} / \mathrm{ml}$ with euthyroid reference interval of $0.485-4.68 \mathrm{uIU} / \mathrm{ml}$.

Reference range for anti- TPO antibodies is negative if less than $10 \mathrm{IU} / \mathrm{ml}$ and positive if more than $10 \mathrm{IU} / \mathrm{ml}$.

Data entry was done in MS. Excel and analysis were done using SPSS16. Statistical analyses were performed using Chi- square and Pearson correlation test. P-value less than 0.05 were statistically significant.

\section{RESULTS}

Serum of 160 individuals with abnormal thyroid function tests was analysed for anti TPO antibody. Among 160 individuals, 126(78.8\%) were females and 34(21.2\%) were males with male to female ratio of 1:2.9. Large number of patients in the present study belonged to $20-39$ years age groups with mean age of $39.07, \mathrm{SD}: \pm 12.84$.

Table 1 shows frequency of various states for thyroid. Subclinical hypothyroidism $(n=90 ; 56.3 \%)$ was more common than overt hyperthyroidism $(n=29 ; 18.0 \%)$, overt hypothyroidism $(\mathrm{n}=27 ; 16.9 \%)$ and subclinical hyperthyroidism $(n=14 ; 8.8 \%)$.

In present study, anti TPO antibody test was positive in $102(63.8 \%)$ cases among them $86(53.8 \%)$ were females and $16(10 \%)$ were males Table 2 . Table 3 displays 49/90 cases of subclinical hypothyroidism and 25/29 cases of overt hypothyroidism with elevated anti-TPOAb. Similarly, Table 4 reveals that $5 / 14$ cases of subclinical hyperthyroidism and 22/27 cases of overt hyperthyroidism showed elevated antiTPOAbs.

Correlation was tested between anti-TPOAbs and hypothyroidism and hyperthyroidism using Pearson's correlation. There is significant positive correlation (Chi- Square test $=9.410, \mathrm{p}$ value $=0.001, \mathrm{r}=0.281$ and $\mathrm{p}$ value $=0.002$ ) between subclinical hypothyroidism and overt hypothyroidism with anti-TPOAbs test. Subclinical hyperthyroidism and overt hyperthyroidism state also showed significant positive correlation (chi-square test $=8.588, \mathrm{p}$ value $=0.005, \mathrm{r}=0.458$ and $\mathrm{P}$ value $=0.003)$ with anti-TPOAbs test (Table 3 and 4) .

At confident interval 95\%, mean serum FT3, FT4 and TSH were $1.99+0.572$ and $1.96+0.530$ and $2.49+0.869 \mathrm{mIU} / \mathrm{L}$ (P-value $<0.0001$ ) respectively (Table 5).

\section{DISCUSSION}

In the present study, among 160 individuals, 126(78.8\%) were females and $34(21.2 \%)$ were males with male to female ratio of 1:2.9. In a study by Ghoraishai et al, $88.04 \%$ were females and $11.96 \%$ were males. Similarly, Shinto et al study also showed female predominance where 91 patients were females and 9 were males. ${ }^{5,6}$

In this study, subclinical hypothyroidism (56.3\%) was more commonly seen than overt hyperthyroidism (18.0\%), overt hypothyroidism $(16.9 \%)$ and subclinical hyperthyroidism $(8.8 \%)$. The results of a study by Hoogendoorn et al showed thyrotoxicosis in $1.2 \%$ (overt in $0.4 \%$, subclinical in $0.8 \%$ ) and hypothyroidism in $4.4 \%$ (overt in $0.4 \%$ and subclinical in $4.0 \%) .{ }^{7}$ According to Legakis et al, overt thyrotoxicosis was found in $4.95 \%$ and subclinical thyrotoxicosis in $5.50 \%$ of total population. ${ }^{8}$ Overt hypothyroidism was found in $1.43 \%$ and subclinical hypothyroidism in $4.51 \%$. In shinto et al study, fifty - nine patient $(59 \%)$ were classified as having Hashimoto's and 41 patients (41\%) were classified as having autoimmune thyroiditis. ${ }^{6}$ 
Table 1: Sex distribution in four categories (subclinhypo/subclinhyper/overthypo/overthyper)

\begin{tabular}{ccccccc}
\hline \multirow{2}{*}{ Sex } & $\begin{array}{c}\text { Subclinical } \\
\text { hypothyroidism }\end{array}$ & hyperthyroidism & overt hypothyroidism & overt hyperthyroidism & Total n (\%) \\
\cline { 2 - 6 } & Frequency (\%) & Frequency (\%) & Frequency (\%) & Frequency & Frequency \\
\hline Male & $23(14.4)$ & $3(1.9)$ & $6(3.8)$ & $2(1.2)$ & $34(21.2)$ \\
Female & $67(41.9)$ & $11(6.8)$ & $21(13.1)$ & $27(16.8)$ & $126(78.8)$
\end{tabular}

Table 2: Evaluation of TPO in percentage in gender

\begin{tabular}{cccc}
\hline \multirow{2}{*}{ Gender } & $<\mathbf{1 0 . 0} \mathbf{I U} / \mathbf{m l}$ & $>\mathbf{1 0 . 0} \mathbf{I U} / \mathbf{m l}$ & Total \\
\cline { 2 - 4 } & Frequency $(\%)$ & Frequency $(\%)$ & Frequency $(5)$ \\
\hline Male & $18(11.2)$ & $16(10.0)$ & $34(21.2)$ \\
Female & $40(25.0)$ & $86(53.8)$ & $126(78.8)$ \\
\hline Total & $\mathbf{5 8 ( 3 6 . 2 )}$ & $\mathbf{1 0 2}(\mathbf{6 3 . 8})$ & $\mathbf{1 6 0}(\mathbf{1 0 0})$ \\
\hline
\end{tabular}

\begin{tabular}{|c|c|c|c|}
\hline \multirow{2}{*}{ TPO } & $\begin{array}{c}\text { Sub clinical } \\
\text { hyperthyroidism }\end{array}$ & $\begin{array}{c}\text { Overt } \\
\text { hyperthyroidism }\end{array}$ & Total \\
\hline & Frequency (\%) & Frequency $(\%)$ & $\begin{array}{c}\text { Frequency } \\
\text { (5) }\end{array}$ \\
\hline Less than 10 & $9(64.3)$ & $5(35.7)$ & $14(100)$ \\
\hline More than 10 & $5(18.5)$ & $22(81.5)$ & $27(100)$ \\
\hline
\end{tabular}

Chi-Square, p-value 0.005, Correlation, $p$ value 0.003

Large number of patients in the present study belonged to 20 - 39 years age group with mean age of $39.07, \mathrm{SD}: \pm 12.84$. Similar results was found in a retrospective crossectional study done in Father Muller Medical college Manglore, in which the average age was 37.16 years. ${ }^{9}$ In the study of Elmugadam AA et al the mean age was 39.3 years where $89.9 \%$ of the patients were females and $10.1 \%$ males. $^{10}$

According to Ghoraishian et al study, $58.42 \%$ of patients with high anti TPO antibody were $20-39$ years old and $89.14 \%$ were females. ${ }^{5}$ In present study, anti TPO antibodies test was shown high in 102/160 (63.8\%) cases among them $86(53.8 \%)$ were female and $16(10 \%)$ were male patients. Similarly, positive anti TPO antibodies test was more in age of 20-39 years (54.9\%) with mean age $38.2 \%$ and standard deviation of 1.13. In the study of Thomas Cyriac et al, most cases with anti TPO antibody positivity were in the 31-40 age groups. The average age of the patient in the study being 35.4 years. ${ }^{11}$

The present study has evaluated anti-TPOAb level in patients with abnormal thyroid function test. In this

Table 3: Relation between anti-TPOAbs and
hypothyroidism
\begin{tabular}{cccc} 
TPO & $\begin{array}{c}\text { Sub clinical } \\
\text { hypothyroidism }\end{array}$ & $\begin{array}{c}\text { Overt } \\
\text { hypothyroidism }\end{array}$ & Total \\
\cline { 2 - 4 } & Frequency (\%) & Frequency (\%) & Frequency (\%) \\
\hline$<10$ & $41(91.1)$ & $4(8.9)$ & $45(100)$ \\
$>10$ & $49(66.2)$ & $25(33.8)$ & $74(100)$
\end{tabular}

Chi-Square, p-value 0.001, Correlation, p value 0.002

study, anti TPO antibody were positive in $62.2 \%$ of hypothyroidism (49/90 cases of subclinical and 25/29 cases of overt hypothyroidism ). Similarly, $65.9 \%$ of cases of hyperthyroidism (5/14 subclinical hyperthyroidism and 22/27 overt hyperthyroidism) showed elevated anti TPO antibodies. Study conducted in Yazd central medical laboratory by physicians in Iran reveal that in cases with high TSH concentration, $35.55 \%$ had normal antiTPO antibody and $64.45 \%$ had abnormal high anti TPO antibody. Kontiainen et al also found elevated levels of anti TPO antibody in $47 \%$ and $12 \%$ of samples with abnormal and normal TSH, respectively. They demonstrated that $61 \%$ of patients with hypothyroidism and $26 \%$ with hyperthyroidism had high level of this antibody. ${ }^{5,12,13}$

Present study showed mean serum FT3, FT4 and TSH as $1.99+0.572, \quad 1.96+0.530$ and $2.49+0.869 \mathrm{mIU} / \mathrm{L}$ (P-value $<0.0001$ ) respectively at confident interval $95 \%$. Madhuvan HS et al showed mean TSH :2.71+/-1.66, T3 :1.20+/-0.52 and T4:6.92+/-1.70. ${ }^{12}$

\section{CONCLUSION}

Anti-TPOAbs are one of the hallmarks of autoimmune thyroid diseases. They are detected in the sera of the majority of subclinical and overt thyroid diseases. If anti$\mathrm{TPOAb}$ is found in subclinical thyroid diseases, Laboratory staff should add a comment regarding the patient at risk of developing overt disease. We, laboratory personnel, can take lead to ensure that these antibodies are estimated to investigate subclinical as well as overt thyroid dysfuction .

\begin{tabular}{|c|c|c|c|c|c|}
\hline Thyroid peroxidase (anti- TPO) antibody test & Mean + Std. deviation & $\mathrm{t}$ - value & p - value & Lower & Upper \\
\hline FT3 & $1.99+0.572$ & 43.971 & 0.000 & 1.90 & 2.08 \\
\hline FT4 & $1.96+0.530$ & 46.672 & 0.000 & 1.87 & 2.04 \\
\hline TSH & $2.49+0.869$ & 36.222 & 0.000 & 2.35 & 2.62 \\
\hline
\end{tabular}

* 95\% Confidence Interval of the Difference 


\section{ACKNOWLEDGEMENT}

I thank to my laboratory staffs/team for their sincere involvement .I also thank to Ashok Pandey for data analysis and management.

\section{Conflict of interest: None}

\section{REFERENCES}

1. Czarnocka B, Eschler DC, Godlewska M, Tomer Y. Thyroid Autoantibodies: Thyroid Peroxidase and Thyroglobulin Antibodies [Internet]. 3rd ed. Autoantibodies: Elsevier; 2013.p 365-75. Crossref

2. McLachlan SM, Rapoport B. Thyroid peroxidase as an autoantigen. Thyroid [Internet]. 2007;17:939-48. Crossref

3. Sinclair D. Thyroid antibodies which why when and who. 2006;6659.

4. Swain M, Swain T, Mohanty BK. Autoimmune thyroid disorders An update. Indian J Clin Biochem [Internet]. 2005;20:9-17. Crossref

5. Ghoraishian SM, Moghaddam SHH, Afkhami-Ardekani M. Relationship between anti-thyroid peroxidase antibody and thyroid function test. Iran J Immunol. 2006;3:146-9. Crossref

6. Shinto AS, Pachen L. Prevalence of antithyroid antibodies in histologically proven autoimmune thyroid diseases and correlation with thyroid dysfunction in South India. Thyroid Sci. 2010;5:15 .

7. Hoogendoorn EH, Hermus AR, De Vegt F, Ross HA, Verbeek ALM, Kiemeney LALM, et al. Thyroid function and prevalence of antithyroperoxidase antibodies in a population with borderline sufficient iodine intake: Influences of age and sex. Clin Chem. 2006;52:10411. Crossref

8. Legakis I, Manousaki M, Detsi S, Nikita D. Thyroid function and prevalence of Anti-Thyroperoxidase (TPO) and anti- thyroglobulin (tg) antibodies in outpatients hospital setting in an area with sufficient iodine intake: Influences of age and sex. Acta Med Iran. 2013;51:2534. Crossref

9. Malathi M, Sudeep K, Jeena Ej. A hospital-based study of anti-TPO titer in patients with thyroid disease. Muller J Med Sci Res [Internet]. 2013;4:74. Crossref

10. Elmugadam AA, Elobied EA, Elebaid MH, Makeen AM. Patients with Thyroid Diseases Design: Prospective study Method: We measured antibodies to thyroglobulin $(\mathrm{TgAb})$ and thyroid peroxidase PDF created with pdfFactory Pro trial version www.p. 2010;2:93-7.

11. Thomas Cyriac, Peter Manoharan Chellappa*, Sinnet P. R. AI. Prevalence of hypothyroidism and its association with anti-thyroid peroxidase antibody among adult sea food consuming population attending a tertiary health care centre in Kerala. Int J Biomed Adv Res [Internet]. 2015;6:79-80. Crossref

12. by Dr. Madhuvan H.S, Dr. Ravishankar S.N, Dr. Somashekar Reddy, Dr.Chandrasekhar P. DN. A prospective study of thyroid dysfunction in elderly patients and its clinical correlation. Arch Med. 2013;5:1-11.

13. Kontiainen S, Melamies L, Miettinen A WT. autoantibodies in serum samples with abnormal TSH levels. APMIS. 1994;102:716-20. Crossref 